\title{
Pengaruh Pemberian Dosis Pupuk Kandang Ayam Petelur Dan NPK Mutiara 16:16:16 Terhadap Pertumbuhan Tanaman Lai Mahakam (Durio Kutejensis Hassk Becc) Belum Menghasilkan
}

\section{Effect of Dose Laying Chicken Manure And Pearls Npk 16:16:16 Against Plant Growth Lai Mahakam (Durio Kutejensis Hassk Becc) Immature}

\author{
Zainudin \\ Tenaga Pedidik Program Studi Agroteknologi, Fakultas Pertanian, Universitas Widya Gama Mahakam Jl. \\ KH. Wahid Hasyim, Sempaja, Samarinda, Kalimantan Timur, Indonesia \\ email : ztjimpolo@gmail.com
}

Diterima : 5 Mei 2016 Disetujui : 23 Juni 2016

\begin{abstract}
This study aims to determine the dose of laying hens manure and fertilizer NPK 16:16:16 Mutiara right and the interaction between the dosing laying hen manure and NPK 16:16:16 pearls in improving plant growth Lai Mahakam immature. The study was conducted over four months, from May to September 2015 starting from land clearance, maintenance of plants, to capture data. This research was conducted at Badak Mekar village, Muara Badak, Regency. The design of the study is a randomized block design factorial $3 \times 3$ with three replications. The first factor is the dose of chicken manure (K) consisting of 3 levels: $K O$ (control), $K 1(10 \mathrm{~kg} /$ plant) and $K 2$ (20 kg / plant). The second factor is the dose of fertilizer NPK 16:16:16 Mutiara (M) comprises 3 levels: MO (Control), M1 (200 g / plant) and M2 (400 g / plant). The treatment dose of chicken manure had no significant effect on all parameters of observation. Treatment fertilizer NPK 16:16:16 Mutiara very significant effect on all parameters of observation. The best treatment for an average plant height increment of age 90 days after treatment was achieved by treatment $M 1(200 \mathrm{~g} /$ plant $)$ is $15.54 \mathrm{~cm}$ while the lowest treatment was achieved by treatment MO (control) is $7.03 \mathrm{~cm}$. Interaction between chicken manure and NPK 16:16:16 Mutiara not significantly affected all parameters of observation.
\end{abstract}

Keywords: Plant Lai Mahakam, Laying Chicken Manure and NPK Mutiara

\section{PENDAHULUAN}

Kalimantan Timur merupakan salah satu provinsi di Indonesia yang memiliki wilayah seluas $127.267,52 \mathrm{~km}^{2}$ dan dilewati oleh garis khatulistiwa. Berdasarkan hal tersebut menjadikan wilayah Kalimantan Timur memiliki tipe iklim yang spesifik, yaitu iklim hutan tropika humida basah (tropical rain forest), ditandai dengan adanya hujan hampir sepanjang tahun dan penyebaran yang merata serta memiliki kelembaban yang tinggi, yang membuat berbagai jenis tanaman tumbuh dengan baik dan beragam seperti halnya tanaman Lai (Anonim, 2015).

Lai Mahakam (Durio kutejensis Hassk Becc) termasuk dalam spesies durian khas Kalimantan Timur. Buah Lai sudah dikenal oleh masyarakat lokal, nasional bahkan mancanegara, hal ini disebabkan karena buah Lai mempunyai karakter yang spesifik dan khas dibandingkan dengan buah durian, antara lain daging buahnya berwarna kuning, rasanya manis dan aroma buah tidak terlalu tajam.

Investasi usaha budidaya tanaman Lai mempunyai prospek yang baik dalam jangka panjang, mengingat harga Lai cenderung meningkat, didukung dengan semua faktor penunjang seperti teknis budidaya, penggunaan pupuk, penggunaan bibit yang tepat kondisi lahan dan pemeliharaan tanaman. Upaya untuk meningkatkan ketersediaan unsur hara dalam tanah diperlukan dalam budidaya tanaman yaitu melalui pemupukan.

Pemupukan akan efektif dan efisien apabila diberikan pada saat yang tepat dengan cara yang benar dan jenis pupuk sesuai dengan kebutuhan unsur hara tanaman. Pupuk organik merupakan pupuk yang bahannya berasal dari bahan organik seperti: tanaman, hewan ataupun limbah organik. Bahan-bahan yang dapat digunakan sebagai pupuk organik misalnya: kotoran hewan, jerami, tanaman perdu, tanaman legum, sekam, dll. Pupuk organik menjadi bahan untuk perbaikan struktur tanah yang terbaik dan alami. Pemberian pupuk organik pada tanah akan memperbaiki struktur tanah dan menyebabkan tanah mampu mengikat air lebih banyak (Mulyani, 2008). 
Penggunaan pupuk anorganik sangat diperlukan untuk memacu pertumbuhan tanaman. Pupuk anorganik mampu meningkatkan produktivitas tanah dalam waktu singkat. Pupuk majemuk merupakan pupuk campuran yang umumnya mengandung lebih dari satu macam unsur hara, makro maupun mikro terutama $\mathrm{N}, \mathrm{P}$ dan $\mathrm{K}$ (Rosmarkam dan Yuwono, 2002). Dengan satu kali pemberian pupuk dapat mencakup beberapa unsur, sehingga lebih efisien bila dibandingkan dengan pupuk tunggal. Kelebihan lain dari penggunaan pupuk

\section{BAHAN DAN METODE}

Penelitian dilaksanakan selama 4 bulan, mulai bulan Mei sampai dengan September 2015. Penelitian ini dilaksanakan di Desa Badak Mekar, Kecamatan Muara Badak, Kabupaten Kutai Kartanegara. Bahan yang digunakan dalam penelitian antara lain : Tanaman Lai Varietas Mahakam berumur 8 bulan, bahan-bahan untuk analisis tanah, pupuk organik kotoran ayam petelur, pupuk NPK Mutiara, Herbisida Gramaxone. Rancangan penelitian yang digunakan adalah rancangan acak kelompok faktorial 3 x 3 dengan 3 kali ulangan. Faktor pertama yaitu pemberian dosis pupuk kandang ayam $(\mathrm{K})$

\section{HASIL DAN PEMBAHASAN}

\section{Pengaruh Pupuk Kandang Ayam Petelur}

Hasil sidik ragam menunjukkan bahwa perlakuan pemberian dosis pupuk kandang ayam petelur tidak berpengaruh nyata terhadap semua parameter pengamatan. Hal ini diduga bahwa kandungan unsur hara yang terdapat di dalam pupuk kandang ayam tidak mampu memenuhi kebutuhan nutrisi yang diperlukan tanaman untuk pertumbuhannya. Kandungan unsur $\mathrm{N}, \mathrm{P}$ dan $\mathrm{K}$ dalam pupuk organik rendah, tetapi pemberian pupuk organik dapat memperbaiki sifat fisik tanah. Sesuai dengan pendapat Novizan (2007), bahwa pupuk organik merupakan pupuk alam dan melepaskan unsur hara secara perlahan-lahan sehingga tidak akan meningkatkan pertumbuhan tanaman secara cepat. Hasil analisis tanah yang dilakukan sebelum dan sesudah perlakuan dapat diketahui bahwa pemberian pupuk kandang ayam yang dilakukan dapat meningkatkan $\mathrm{pH}$ dari 3,5 menjadi 6,56. Derajat keasaman tanah menggambarkan banyaknya ion hidrogen yang majemuk NPK yaitu menghemat waktu, tenaga kerja dan biaya pengangkutan (Hardjowigeno, 2007).

Pupuk anorganik mampu meningkatkan produktivitas tanah dalam waktu singkat, tetapi penggunaan yang dilakukan secara terus menerus akan mengakibatkan kerusakan pada struktur tanah (tanah menjadi keras) dan menurunkan produktivitas tanaman yang dihasilkan (Mulyani, 2008). Oleh karena itu pemberian pupuk anorganik perlu diimbangi dengan pemberian pupuk organik agar penurunan kualitas tanah dapat dikurangi.

tediri dari 3 taraf: $\mathrm{k} 0$ (kontrol), $\mathrm{k} 1 \quad$ (10 $\mathrm{kg} /$ tanaman) dan $\mathrm{k} 2$ (20 kg/tanaman). Faktor kedua adalah pemberian dosis pupuk NPK Mutiara 16:16:16 (M) terdiri 3 taraf : $\mathrm{m}_{0}$ (kontrol), $\mathrm{m}_{1}(200 \mathrm{~g} / \mathrm{tanaman})$ dan $\mathrm{m}_{2}$ (400 $\mathrm{g} /$ tanaman). Parameter yang diamati dalam penelitian ini yaitu : pertambahan tinggi tanaman , pertambahan diameter batang, pertambahan jumlah daun dan analisis tanah. Data yang diperoleh dianalisis dengan menggunakan sidik ragam, apabila terdapat pengaruh pada sidik ragam maka dilakukan uji BNT pada taraf 5\% untuk membandingkan data rata-rata perlakuan.

terdapat di dalam tanah. Disamping itu pemberian pupuk kandang ayam juga meningkatkan kapasitas tukar kation (KTK) dari 2,42 (perlakuan a0m0) menjadi 38,4 (perlakuan a2m0) dan juga menaikkan kejenuhan basa (KB) dari 25,7 (perlakuan $\mathrm{a} 0 \mathrm{~m} 0$ ) menjadi 83,8 (perlakuan a2m0) (Tabel 15). Dari data tersebut terlihat bahwa walaupun tidak memberikan pengaruh yang nyata terhadap pertumbuhan tanaman namun penggunaan pupuk kandang ayam dapat memperbaiki struktur tanah dan aerasi tanah.

Menurut (Marsono dan Lingga, 2010) bahwa penggunaan pupuk kandang kotoran ayam mempunyai beberapa keuntungan antara lain sebagai pemasok hara tanah dan meningkatkan retensi air. Apabila kandungan air tanah meningkat, proses perombakan bahan organik akan banyak menghasilkan asam-asam organik. Anion dari asam organik dapat mendesak fosfat yang terikat oleh $\mathrm{Fe}$ dan $\mathrm{Al}$ sehingga fosfat dapat terlepas dan tersedia bagi tanaman. Penambahan kotoran ayam berpengaruh positif pada tanah masam berkadar bahan organik rendah karena pupuk 
organik mampu meningkatkan kadar $\mathrm{P}, \mathrm{K}, \mathrm{Ca}$

\section{Pengaruh Pupuk NPK Mutiara 16:16:16}

Hasil sidik ragam menunjukkan bahwa perlakuan pemberian dosis pupuk NPK Mutiara 16:16:16 berpengaruh nyata terhadap semua parameter pengamatan yaitu rata-rata pertambahan tinggi tanaman umur 30, 60 dan 90 hari setelah perlakuan dan pertambahan diameter batang umur 30, 60 dan 90 hari setelah perlakuan dan rata-rata jumlah daun dan $\mathrm{Mg}$ tersedia.

umur 30, 60 dan 90 hari setelah perlakuan. Hal ini diduga bahwa tanaman memerlukan unsur hara yang optimum diawal pertumbuhannya, yang bertujuan untuk memperlancar proses metabolisme pada fase vegetatif. Kandungan unsur $\mathrm{N}, \mathrm{P}$ dan $\mathrm{K}$ yang terdapat dalam pupuk NPK Mutiara 16:16:16 dapat diserap dengan baik oleh tanaman untuk perkembangan vegetatif tanaman.

Tabel 1. Pertambahan tinggi tanaman $(\mathrm{cm})$ pada perlakuan pupuk NPK Mutiara 16:16:16

\begin{tabular}{cccc}
\hline \multirow{2}{*}{ Perlakuan NPK } & \multicolumn{3}{c}{ Umur tanaman (hst) } \\
\cline { 2 - 4 } & 20 & 60 & 90 \\
\hline $\mathrm{m} 0$ & $2,58^{\mathrm{b}}$ & $3,31^{\mathrm{b}}$ & $7,03^{\mathrm{b}}$ \\
$\mathrm{m} 1$ & $3,90^{\mathrm{a}}$ & $5,31^{\mathrm{a}}$ & $15,54^{\mathrm{a}}$ \\
$\mathrm{m} 2$ & $2,81^{\mathrm{ab}}$ & $3,32^{\mathrm{b}}$ & $9,97^{\mathrm{ab}}$ \\
\hline
\end{tabular}

Keterangan : Angka-angka yang diikuti huruf yang sama menunjukkan tidak berbeda nyata pada uji BNT $5 \%$

Tabel 2. Pertambahan diameter batang tanaman $(\mathrm{cm})$ pada perlakuan pupuk NPK Mutiara 16:16:16

\begin{tabular}{cccc}
\hline \multirow{2}{*}{ Perlakuan NPK } & \multicolumn{3}{c}{ Umur tanaman (hst) } \\
\cline { 2 - 4 } & 20 & 60 & 90 \\
\hline $\mathrm{m} 0$ & $0,04^{\mathrm{b}}$ & $0,14^{\mathrm{b}}$ & $0,34^{\mathrm{b}}$ \\
$\mathrm{m} 1$ & $0,10^{\mathrm{a}}$ & $0,42^{\mathrm{a}}$ & $0,66^{\mathrm{a}}$ \\
$\mathrm{m} 2$ & $0,07^{\mathrm{ab}}$ & $0,16^{\mathrm{b}}$ & $0,50^{\mathrm{ab}}$ \\
\hline
\end{tabular}

Keterangan : Angka-angka yang diikuti huruf yang sama menunjukkan tidak berbeda nyata pada uji BNT 5\%

Tabel 3. Pertambahan jumlah daun (helai) pada perlakuan pupuk NPK Mutiara 16:16:16

\begin{tabular}{cccc}
\hline \multirow{2}{*}{ Perlakuan NPK } & \multicolumn{3}{c}{ Umur tanaman (hst) } \\
\cline { 2 - 4 } & 20 & 60 & 90 \\
\hline $\mathrm{m} 0$ & $5,67^{\mathrm{b}}$ & $8,67^{\mathrm{b}}$ & $11,67^{\mathrm{b}}$ \\
$\mathrm{m} 1$ & $6,78^{\mathrm{b}}$ & $9,67^{\mathrm{b}}$ & $14,11^{\mathrm{b}}$ \\
$\mathrm{m} 2$ & $9,78^{\mathrm{a}}$ & $13,11^{\mathrm{a}}$ & $17,33^{\mathrm{a}}$ \\
\hline
\end{tabular}

Keterangan : Angka-angka yang diikuti huruf yang sama menunjukkan tidak berbeda nyata pada uji BNT 5\%

Sesuai dengan pendapat (Marsono dan Lingga, 2010), bahwa unsur $N, P$, dan $K$ dapat meningkatkan pertumbuhan tanaman. Nitrogen mempunyai peranan penting bagi tanaman untuk merangsang pertumbuhan vegetatif yaitu menambah tinggi tanaman dan membuat tanaman menjadi lebih hijau karena merupakan bahan penyusun klorofil yang penting dalam fotosintesis. Unsur $\mathrm{P}$ dapat meningkatkan laju fotosintesis dan merangsang pembentukan daun baru yang menyebabkan berat kering tanaman bertambah, selain itu unsur $P$ diperlukan untuk merangsang pertumbuhan akar, pembentukan bunga dan buah. Kalium mempunyai peranan penting terhadap peristiwa fisiologis tanaman, diantaranya yaitu pengaktif dari sejumlah besar enzim yang penting untuk fotosintesis, respirasi, pembentukan pati dan protein. 


\section{Interaksi Perlakuan}

Hasil sidik ragam menunjukkan bahwa interaksi pemberian pupuk kandang ayam petelur dan NPK Mutiara 16:16:16 tidak berpengaruh nyata terhadap semua parameter pengamatan. Tidak adanya pengaruh nyata ini karena perlakuan pemberian pupuk kandang ayam petelur dan pupuk NPK Mutiara 16:16:16 tidak terdapat hubungan yang saling mempengaruhi, kedua faktor perlakuan tersebut bertindak bebas satu sama lainnya. (Harjadi, 2002), menyatakan bahwa

\section{Analisis Tanah}

Hasil analisis tanah setelah diberi perlakuan dapat dilihat kombinasi perlakuan $\mathrm{K}_{2} \mathrm{M}_{1}$ menunjukan kondisi keasaman tanah netral, kondisi bahan organik yang lebih tinggi dibandingkan dengan perlakuan yang lain. Pemberian kombinasi pupuk organik dan anorganik dapat meningkatkan kandungan unsur hara di dalam tanah dan memperbaiki Tabel 4 : Hasil Analisis Tanah Setelah Dilakukan Perlakuan

\begin{tabular}{|c|c|c|c|c|c|c|c|c|c|c|}
\hline \multirow{2}{*}{ Kode } & \multirow{3}{*}{$\mathrm{pH}$} & $\mathrm{N}$ & $\mathrm{P}$ & $\mathrm{K}$ & \multicolumn{4}{|c|}{ Kation Basa (pH 7) } & \multirow{2}{*}{ KTK } & \multirow{2}{*}{ Kej. Basa \% } \\
\hline & & Total & \multicolumn{2}{|c|}{ Tersedia } & $\mathrm{Ca}^{++}$ & $\mathrm{Mg}^{++}$ & $\mathrm{K}^{+}$ & $\mathrm{Na}^{+}$ & & \\
\hline Sampel & & $\%$ & \multicolumn{2}{|c|}{ Ppm } & \multicolumn{5}{|c|}{$\mathrm{Me} / 100 \mathrm{~g}$} & \\
\hline $\mathrm{K}_{0} \mathrm{M}_{0}$ & 4,05 & 0,22 & 5,27 & 116,8 & 3,66 & 1,28 & 0,80 & 0,49 & 24,2 & 25,7 \\
\hline $\mathrm{K}_{0} \mathrm{M}_{1}$ & 5,95 & 0,52 & 789,9 & 1453,8 & 13,93 & 4,88 & 6,35 & 2,64 & 32,2 & 86,3 \\
\hline $\mathrm{K}_{0} \mathrm{M}_{2}$ & 4,28 & 0,24 & 138,3 & 202,7 & 5,19 & 1,82 & 2,15 & 0,98 & 15,7 & 64,6 \\
\hline $\mathrm{K}_{1} \mathrm{M}_{0}$ & 6,65 & 0,64 & 1260,4 & 765,3 & 10,47 & 3,67 & 5,49 & 2,83 & 30,3 & 74,1 \\
\hline $\mathrm{K}_{1} \mathrm{M}_{1}$ & 6,97 & 0,59 & 1405,7 & 1503,4 & 13,68 & 4,79 & 7,31 & 3,73 & 32,3 & 91,4 \\
\hline $\mathrm{K}_{1} \mathrm{M}_{2}$ & 5,83 & 0,18 & 322,1 & 505,2 & 8,43 & 2,95 & 2,86 & 1,39 & 34,8 & 44,9 \\
\hline $\mathrm{K}_{2} \mathrm{M}_{0}$ & 6,56 & 0,55 & 1021,5 & 1037,6 & 18,27 & 6,39 & 4,89 & 2,61 & 38,4 & 83,8 \\
\hline $\mathrm{K}_{2} \mathrm{M}_{1}$ & 7,07 & 0,66 & 1537,5 & 1896,7 & 19,96 & 6,99 & 9,37 & 4,82 & 40,7 & $>100$ \\
\hline $\mathrm{K}_{2} \mathrm{M}_{2}$ & 6,41 & 0,40 & 109,9 & 662,5 & 14,70 & 5,14 & 4,25 & 2,11 & 33,1 & 79,2 \\
\hline
\end{tabular}

Sumber : Laboratorium Tanah Fakultas Pertanian Universitas Mulawarman

Pada kombinasi perlakuan $\mathrm{K}_{0} \mathrm{M}_{0}$ dapat dilihat kondisi tanah masih tergolong asam dan kandungan unsur hara sedikit. Sifat kimia tanah setelah diberi perlakuan dikategorikan rendah. Walaupun dilakukan penggemburan tanah disekitar lingkungan tumbuh tanaman namun tanpa penambahan unsur hara, pertumbuhan tanaman menjadi lambat. Sesuai dengan pendapat Harjadi (2002), bahwa laju

\section{KESIMPULAN}

1. Perlakuan pemberian dosis pupuk kandang ayam petelur tidak berpengaruh nyata terhadap semua parameter pengamatan, tetapi dapat meninggkatkan $\mathrm{pH}$ tanah, KTK dan kejenuhan basa tanah. perbedaan jenis dan dosis pemupukan yang diberikan akan mempengaruhi kemampuan tanaman dalam menyerap unsur hara dan juga mempengaruhi keadaan fisiologis dan daya tanggap yang berbeda terhadap lingkungan.

Menurut Steel dan Torie (1993), apabila interaksi antara perlakuan yang satu dengan yang lain tidak berbeda nyata, maka dapat disimpulkan bahwa faktor-faktor tersebut bertindak bebas satu sama lain, pengaruh sederhana suatu faktor sama pada semua taraf faktor lainnya.

struktur tanah, yang pada akhirnya akan mempengaruhi pertumbuhan tanaman. Sifat kimia tanah setelah diberi perlakuan dikategorikan tinggi. Sesuai dengan pendapat Menurut Mulyani (2008), bahwa pertumbuhan tanaman akan berlangsung baik apabila struktur dan kadar unsur hara yang terkandung dalam tanah tempat tumbuhnya masih baik. fotosintesis untuk produksi asimilat tentu sangat dipengaruhi oleh ketersediaan unsur hara, bila laju pembelahan sel lambat, pertumbuhan batang, daun dan perakaran dengan sendirinya akan lambat karena pembelahan dan pembesaran pembentukan jaringan memerlukan persediaan karbohidrat yang digunakan dalam proses pertumbuhan dan perkembangan batang, daun dan akar.

2. Perlakuan pemberian pupuk NPK Mutiara 16:16:16 berpengaruh sangat nyata terhadap semua parameter pengamatan. Perlakuan yang terbaik untuk rata-rata pertambahan tinggi tanaman umur 90 hari setelah perlakuan dicapai pada perlakuan 
$\mathrm{M}_{1} \quad(200 \mathrm{~g} /$ tanaman $)$ yaitu $15,54 \mathrm{~cm}$ sedangkan perlakuan terendah dicapai pada perlakuan $\mathrm{M}_{0}$ (kontrol) yaitu 7,03 $\mathrm{cm}$.

\section{DAFTAR PUSTAKA}

Anonim. 2003. Studi Tentang Eksplorasi Tanaman Lai. Bidang Ekonomi dan Keuangan Proyek Penelitian dan Pengembangan Daerah Propinsi Kalimantan Timur.

Anonim. 2005. Pelepasan Kultivar Lai. Laporan Penelitan, Balitbangda Prov. Kaltim, Faperta Unmul, UPT. PSBTPH dan Distan Kab. Kukar, Kalimantan Timur.

Anonim, 2015. Profil Wilayah Kalimantan Timur. www.bappedakaltim com. diakses tanggal 23 april 2015.

Goenadi, D.H. 2006. Pupuk dan Teknologi Pemupukan berbasis Hayati dari Cawan Petri ke Lahan Petani. Yayasan John Hi-Tech Idetama. Jakarta.

Hanafiah, K.A, 2003. Rancangan Percobaan Teori \& Aplikasi. Rajawali Pers. Palembang.

Hardjowigeno, S. 2007. Ilmu Tanah. Akademika Pressindo. Jakarta.

Harjadi, S.S. 2002. Pengantar Agronomi. Gramedia Pustaka. Jakarta.

Jumin, H.B. 2002. Dasar-Dasar Agronomi. Rajawali Press. Jakarta.

Lingga, P. 2008. Petunjuk Penggunaan Pupuk. Penebar Swadaya. Jakarta.

Marsono dan Lingga, P. 2010. Petunjuk Penggunaan Pupuk. Penebar Swadaya. Jakarta.

Mulyani, M. 2008. Pupuk dan Cara Pemupukan. Rineka Cipta. Jakarta.
3. Interaksi antara pemberian pupuk kandang ayam petelur dan NPK Mutiara 16:16:16 tidak berpengaruh nyata terhadap semua parameter pengamatan.

Nursyamsi, D., Husnaen, A. Kasno, dan D. Setyorini. 2005. Tanggapan Tanaman Jagung (Zea mays, L.) Terhadap Pemupukan MOP Rusia pada Inceptisols dan Ultisols. Hal. 13-23. Jurnal Tanah dan Iklim No. 23, Desember 2005. Balai Besar Litbang Sumberdaya Lahan Pertanian. Bogor.

Novizan. 2007. Petunjuk Pemupukan yang Efektif. Agro Media Pustaka. Jakarta.

Pranata, S Ayub. 2004. Pupuk Organik Cair Aplikasi dan Manfaatnya, Agromedia Pustaka. Tangerang.

Rauf, A.W., T. Syamsuddin, S. R. Sihombing. 2000. Peranan Pupuk NPK pada Tanaman Padi. Loka Pengkajian Teknologi Pertanian No. 01/LPTP/IRJA/ 99-00. Samarinda.

Rosmarkam, A. dan N. W. Yuwono. 2002. Ilmu Kesuburan Tanah. Kanisius. Yogyakarta.

Rukmana, R. 1999. Durian. Kanisius. Yoyakarta.

Steel, R. G. D. and Torrie, J. H. 1993. Principles and Procedur of Statistic (Terjemahan Bambang Sumantri, Prinsip dan Prosedur Statistika). Gramedia. Jakarta.

Wahidah. 2003. Budidaya Pempaken http://hanayessy89.blogspot.com. Diakses tanggal 15 Mei 2012.

Winarso, S. 2005. Kesuburan Tanah Dasar Kesehatan dan Kualitas Tanah. Gaya Media. Yogyakarta. 
